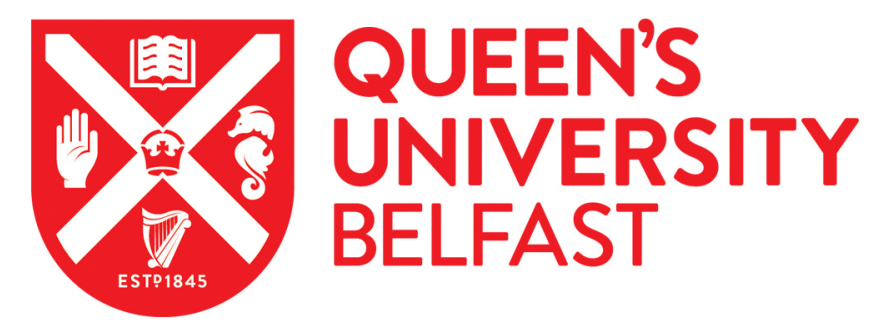

\title{
A new species of Callochiton (Mollusca: Polyplacophora) from the Strait of Messina (central Mediterranean)
}

Dell'Angelo, B., Renda, W., Sossa, M., Sigwart, J., \& Giacobbe, S. (2017). A new species of Callochiton (Mollusca: Polyplacophora) from the Strait of Messina (central Mediterranean). Archiv für Molluskenkunde International Journal of Malacology, 146, 243-250. https://doi.org/10.1127/arch.moll/146/243-250

Published in:

Archiv für Molluskenkunde - International Journal of Malacology

Document Version:

Early version, also known as pre-print

Queen's University Belfast - Research Portal:

Link to publication record in Queen's University Belfast Research Portal

Publisher rights

Copyright 2018E Schweizerbart Science Publishers. This work is made available online in accordance with the publisher's policies. Please refer to any applicable terms of use of the publisher.

\section{General rights}

Copyright for the publications made accessible via the Queen's University Belfast Research Portal is retained by the author(s) and / or other copyright owners and it is a condition of accessing these publications that users recognise and abide by the legal requirements associated with these rights.

Take down policy

The Research Portal is Queen's institutional repository that provides access to Queen's research output. Every effort has been made to ensure that content in the Research Portal does not infringe any person's rights, or applicable UK laws. If you discover content in the Research Portal that you believe breaches copyright or violates any law, please contact openaccess@qub.ac.uk. 


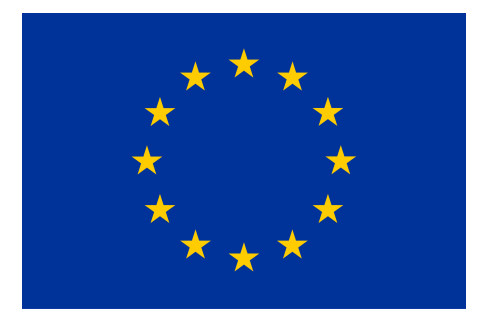

This project has received funding from the European Union's Horizon 2020 research and innovation programme under the Marie Skłodowska-Curie grant agreement No H2020-MSCAIF-2014-655661.

This copy of the accepted manuscript is provided to enable dissemination through Open Access to the scientific data; the version of record is that provided by the publishers. 
A new species of Callochiton (Mollusca: Polyplacophora)

from the Strait of Messina (central Mediterranean)

\author{
Bruno Dell'Angelo, Walter Renda, \\ Maurizio Sosso, Julia D. Sigwart \& Salvatore Giacobbe
}

Bruno DELL'ANGELO' ${ }_{(\circledast)}$, Walter RENDA², Maurizio $\mathrm{SOSSO}^{3}$, Julia D. SIGWART ${ }^{4} \&$ Salvatore GIACOBBE ${ }^{5}$

${ }^{1}$ Museo di Zoologia, Via Selmi 3, 40126 Bologna, Italy - [bruno.dellangelo@chitons.it]

(®) corresponding author

${ }^{2}$ Via Bologna 18/A, 87032 Amantea (CS), Italy - [w.renda1@tin.it]

${ }^{3}$ Via Bengasi 4, 16153 Genova, Italy - [sosmauri@gmail.com]

${ }^{4}$ Marine Laboratory, Queen's University Belfast, Portaferry, N. Ireland - [julia.sigwart@qub.ac.uk]

${ }^{5}$ Department of Chemical, Biological, Pharmaceutical and Environmental Sciences, University of Messina, Viale F. Stagno d'Alcontres 31, 98166 Messina, Italy.- [sgiacobbe@unime.it]

\begin{abstract}
A new species of Callochiton, C. $X X X X X X X X$ n. sp., has been identified in the framework of investigations aimed to better characterize the Strait of Messina benthic ecosystem. The new species, exclusively found in a peculiar facies of hard bottoms densely colonized by the hydrocoral Errina aspera (Linnaeus, 1767), is morphological distinct from the co-generic Callochiton septemvalvis (Montagu, 1803), living in European seas, and C. doriae (Capellini, 1859), living in the Mediterranean Sea.
\end{abstract}

Key words: Mollusca, Polyplacophora, Callochiton, Recent, Strait of Messina, new species. 


\section{INTRODUCTION}

Three species of Callochiton Gray, 1847 are known from the Atlantic coasts of Europe and the Mediterranean Sea. Callochiton calcatus Dell'Angelo \& Palazzi, 1994 is a rare species restricted to the Mediterranean. The other two species, C. septemvalvis (Montagu, 1803), living in European seas, and C. doriae (Capellini, 1859), living in the Mediterranean Sea, are very similar to each other, differing mainly by the absence or presence of longitudinal grooves on the pleural areas of the intermediate valves and antemucronal area of the tail valve. There was previously some room for doubt about whether these two morphotypes represented distinct species, or rather the morphological plasticity of C. septemvalvis (e.g. THIELE 1902; BERGENHAYN 1931; LeLOUP 1934; KAAS 1978; CARMONA ZALVIDE et al. 2002). Individuals attributed to both these species of Callochiton were included in a molecular phylogeny published by by SIGWART et al. (2013) with one specimen of $C$. septemvalvis from France (Roscoff, Atlantic Ocean) and one of C. "euplaeae" (O.G. Costa, 1830) (not 1829 as usually indicated, see FASUlO 2013) from Croatia (Adriatic Sea). However, the taxon Callochiton euplaeae is a nomen dubium, as reported by DELL'ANGELO et al. (2016). To clarify, considering the more appropriate available name $C$. doriae, the Mediterranean members of the species of Callochiton without longitudinal grooves on the pleural areas should be attributed to Callochiton septemvalvis, whilst the species with longitudinal grooves is Callochiton doriae.

In this paper, we describe some small specimens of Callochiton sampled in the framework of research cruises carried out in a peculiar habitat of the Strait of Messina. These specimens lack longitudinal grooves (the key character for separating $C$. septemvalvis and $C$. doriae), yet differ from other congeners, and they are therefore described as a new species, $C . X X X X X X X X \mathrm{n}$. sp.

The Strait of Messina (Fig. 1) is characterized by strong tidal currents which create a constant upwelling regime. Such peculiar hydrology makes the area distinct from the major Mediterranean sectors, it is noted as hosting "a wealth of biogeographic peculiarities, including Pliocene Atlantic remnants and local endemisms" (BIANCHI et al. 2012), and recent studies of the region have frequently described new species (BOGI \& CAMPANI 2006, 2007; BUZZURRO \& RUSSO 2007; BOGI \& BARTOLini 2008; CROCETTA et al. 2009; Tisselli et al. 2009; Bogi et al. 2016; ReNDA \& MiCALI 2016; SMRIGLIO et al. 2016), all of which combine to make the Strait an apparent biodiversity hotspot. One of the most peculiar environments of the Messina Strait is probably the "Sill", a rough seafloor that connects the Calabrian and Sicilian continental slope, where it extends southernmost throughout Rada Paradiso (GIACOBBE et al. 2007). Such steep hard bottoms are densely colonized by the hydrocoral Errina aspera (Linnaeus, 1767), representing an exclusive facies from the 
subtidal-bathyal transition (Di GERONIMO \& FREDJ 1987).

\section{MATERIALS AND METHODS}

From the "Sill" in the Strait of Messina, twenty small sized specimens of Callochiton sp. were sampled in the framework of two distinct cruises (Errina'87 and POP'95) sponsored by the University of Messina (Table 1), aimed to better define the distribution of the hydrocoral-dominated biotope (GIACOBBE 2001; GIACOBBE et al. 2007) and to investigate the major associated species (GiacobBe \& Rineldi 1991; GiacobBe \& Spanò 2001). The Callochiton specimens were also compared with other material collected by fishing boats at different times from the same area.

Morphological features and diagnostic characters of the chiton specimens were studied and detected by scanning electron microscope (SEM) at the Messina University. The digital images were obtained using a Motic SMZ-140 Microscope with the software Motic Images Plus.

The following abbreviations are used:

BD B. DeLL'ANGELo Collection, Genova, Italy (will be deposited in MZB)

BEL Benthic Ecology Laboratory, Department of Chemical, Biological, Pharmaceutical and Environmental Sciences, University of Messina, Italy

MS M. Sosso Collection, Genova, Italy

MZB Museo di Zoologia dell’Università di Bologna, Bologna, Italy

POP Programma Operativo Plurifondo, Sicilia 1994-99

SMF Senckenberg Forschungsinstitut und Naturmuseum, Frankfurt a. Main, Germany;

spm specimen

WR W. RENDA Collection, Amantea (CS), Italy

\section{SYSTEMATICS}

Class Polyplacophora Gray, 1821

Order Chitonida Thiele, 1909

Family Callochitonidae Plate, 1901

Genus Callochiton Gray, 1847

Type species. Chiton laevis Montagu, 1803 (non Pennant, 1777) [= Callochiton septemvalvis (Montagu, 1803), fide KAAS 1978] by subsequent designation (GRAY 1847). 
Distribution. Tropical and subtropical regions of the Indo-Pacific (including Japan; absent from the northeastern Pacific). In the Atlantic Ocean restricted to the eastern part and to sub-Antarctic and Antarctic part (KAAS \& VAN BeLlE 1985). Neogene - Recent.

\section{Callochiton $X X X X X X X X$ n. sp.}

Figures 2-4

Type material. Holotype: MZB 32137, spm disarticulated and coated for SEM analysis, length 4.3 mm (Figs 3A-N). Paratype: BEL 117 POP'95 DG11, length 2 mm.

Material examined. The type material and 18 specimens were collected from the sites reported in Table 1. An additional six specimens are in the BD collection from separate collected events, all from fishing boats working in the Strait in environments colonized by Errina aspera, and probably coming from the Sill in the Strait of Messina. All the material examined is reported in Table 2. Type locality. Strait of Messina, Rada Paradiso, dredging station DG11 (Table 1, Figure 1). Etymology. The species is named after Stefania Minerva, the last author's wife and herself a marine biologist.

Diagnosis. Animal of small size, ovate, moderately elevated, tegmentum and girdle uniformly coloured from very light brownish to rosaceous. Tail valve semicircular, with a small, hardly raised mucro in anterior position, antemucronal and postmucronal slopes straight. Tegmentum surface appears rough, sculptured with fine, tabulate elongate granules, well separated on the lateral areas and fusing into continuous lines in the central areas. Slit formula 17/2/14. Girdle wide, densely covered with fine, smooth, dorsal imbricating spicules, a marginal fringe of lanceolate spicules, and ventral small, flat spicules. Radula with 30 transverse rows of mature teeth, major lateral tooth with a tridentate cusp, the denticles of almost equal length.

Description. Animal of small size, $4.3 \mathrm{~mm}$ in length, ovate, moderately elevated, girdle rather wide, tegmentum and girdle uniformly coloured from very light brownish to rosaceous.

Head valve semicircular with almost straight anterior slope, posterior margin widely Vshaped, without central posterior notch. Intermediate valves rectangular, subcarinate with the top rounded, dorsal elevation 0.36 (valve IV; fig. 3I), anterior margin almost straight, side margins rounded, posterior margin slightly concave at both sides of the well pronounced apex, lateral areas moderately raised. Tail valve semicircular, anterior margin slightly convex, with a small, hardly raised mucro in anterior position, antemucronal and postmucronal slopes straight. 
Tegmentum surface appears rough, sculptured with fine, tabulate elongate granules, well separated on the lateral areas and fusing into continuous lines in the central areas (Figs 3H, 4D). Overall appearance of valves is finely striated when examined under magnification, striae longitudinally oriented in central and antemucronal areas, radially oriented in head valve, lateral areas and postmucronal area, marked with a few concentric growth lines toward the outer margins.

Articulamentum rose coloured in the centre, whitish towards the sides, apophyses wide, short, regularly rounded, connected at the jugum by a lamina, insertion plates short, slit formula 17/2/14, teeth irregular, slit rays scarcely visible, eaves very porous, apical area of head and intermediate valves marked by longitudinal fine furrows (Figs 3L-M).

Girdle wide, densely covered with fine, straight, smooth, imbricating spicules, closely tightened to the surface, directed inward, ca. 75-95 x 21-25 $\mu \mathrm{m}$ (in situ), oval in diameter. Some slender, smooth, curved spines, 230-260 $\mu \mathrm{m}$ long (measured in spm MZB 32138 in situ) are found close to the outer margin (Figs $4 \mathrm{~J}-\mathrm{K}$ ). There is a marginal fringe of lanceolate, feather-like striated, somewhat flattened spicules, ca. 87-97 $\mu \mathrm{m}$ long and 22-24 $\mu \mathrm{m}$ wide. Ventral side covered with transverse rows of small, bluntly pointed, flat spicules, ca. $50 \mu \mathrm{m}$ long (measured in spm MZB 32138 in situ).

Radula with 30 transverse rows of mature teeth, asymmetric, central tooth with a narrow blade, first lateral teeth distally widening, major lateral tooth with a tridentate cusp, the denticles of almost equal length.

Remarks. No trace of grooves was found in the central areas of any of the listed specimens examined from the Strait of Messina, contrary to what observed on other specimens of Callochiton collected along the coasts of Calabria and Sicily of the Strait and attributed to Callochiton doriae, which always have conspicuous longitudinal grooves, even as juveniles (MONTEROSATO 1879; Giovine \& DeLL'Angelo 1993).

The valves of the specimen disarticulated for SEM analysis (Figs 3G-N) are quite eroded and some features (especially in the articulamentum) are not clear, so we present additional images of valves (Figs 4A-I) from another specimen from DG04 (broken in half and therefore not counted in the material examined) with the valves better preserved. The girdle of this specimen also includes some irregularly spaced much longer needles dorsal to the marginal fringe in the form of ringshaftneedles (ca $260 \mu \mathrm{m}$ long; Fig 4J-K).

Callochiton $X X X X X X X X$ n. sp. differs from $C$. doriae and C. septemvalvis by the following features:

(a) the smaller size, up to $24 \mathrm{~mm}$ in length for $C$. doriae (DELL'ANGELO \& PALAZZI 1994) and 
$22 \mathrm{~mm}$ for C. septemvalvis (CARMONA ZALVIDE et al. 2002), vs. up to $4.6 \mathrm{~mm}$ for C. $X X X X X X X X$;

(b) the uniform very light brownish to rosaceous colour, both for the tegmentum and for the girdle, vs. a variable colour in C. doriae / C. septemvalvis, which are more or less variegated with spots of various colours, and often with lighter colored bands on the girdle (KAAS \& VAN BELLE 1985; Dell'Angelo \& SMriglio 1999);

(c) the shape of tail valve, with the mucro central in C. doriae / C. septemvalvis (e.g. KAAS \& VAn Belle 1985: fig. 2.8-9; Dell'Angelo \& SMriglio 1999: pl. 40, fig. G, pl. 41 fig. J), in anterior position in C. $X X X X X X X X$ (Figs 3J-K);

(d) the different size of dorsal girdle spicules, 150-280 x 25-32 $\mu \mathrm{m}$ in C. septemvalvis / C. doriae (KAAs \& VAN Belle 1985) vs. 75-90 x 21-25 $\mu \mathrm{m}$ in C. XXXXXXXX. CARMONA ZALVIDE et al. (2002) give 130-190 x 50-60 $\mu \mathrm{m}$ for C. doriae, 100-200 x 50-100 $\mu \mathrm{m}$ for C. septemvalvis.

(e) the lack of longitudinal grooves on the central areas, always evident in C. doriae including in juvenile specimens. We include SEM photos of two juvenile specimens of $C$. doriae, for comparison (Figs 5A-C).

Callochiton $X X X X X X X X \mathrm{n}$. sp. differs from C. calcatus by the shape of the valves, strongly angulated and elevated in C. calcatus (dorsal elevation $0.65-0.72$ vs. 0.36 in $C . X X X X X X X X$ n. sp.), the postmucronal slope of tail valve, convex and very characteristic in C. calcatus (see Dell'Angelo \& SMriglio 1999: p. 133, fig. 7B), the intermediate valves trapezoidal in $C$. calcatus, and moreover the lack of longitudinal grooves on the central areas in C. $X X X X X X X X \mathrm{n}$. sp., well evidenced in C. calcatus.

Species in the genus Callochiton possess pigmented aesthetes (BAXTER \& JONES 1984; SCHWABE 2010). Only a subset of the shell pores associated with the aesthete system found in Callochiton spp. contain pigments. The pigmented aesthetes in Callochiton spp. are regularly arranged over the shell lateral areas and in radial rows in the head and postmucronal area of the tail valve (BAXTER \& JONES 1984), and are surprisingly difficult to see, the visibility depending on the direction on view too. We were not able to confirm the presence of pigmented aesthetes in $C$. $X X X X X X X X$ but we also cannot confirm their absence. The lacking of visible pigments in aesthetes has been already reported in literature (e.g. DELL'ANGELO et al. 2012 for Callochiton cupreus Dell'Angelo, Prelle, Sosso \& Bonfitto, 2012 from Madagascar).

The longitudinal fine furrows present in the apical area of head and intermediate valves (Fig. 3L-M) seem of particular interest. The apical areas of Callochiton septemvalvis / C. doriae are smooth, which has not been previously noted but is apparent from published SEM images of those species (BAXTER \& Jones 1984: pl. 4, figs (a), (c); Dell'ANGelo \& SMriglio 1999: pl. 40, figs D, F). Likewise, these fine furrows are not visible in the other Mediterranean Callochiton species, $C$. 
calcatus. Any functional significance of the peculiar furrows is unclear, and awaits further studies.

With this material, as for many chitons so far, there are very few data available for molecular genetic comparisons. With regard to Callochiton septemvalvis / C. doriae, to our knowledge only two specimens have been sequenced for C. septemvalvis (OKUSU et al. 2003, SIGWART et al. 2013), and 1 specimen for $C$. doriae (SIGWART et al. 2013). We have established here the distinctive morphologies of Callochiton septemvalvis / C. doriae, but we note that there may be more hidden diversity within the Atlantic and Mediterranean members of Callochiton.

The habitat of C. $X X X X X X X X$ is different from those known for C. doriae / C. septemvalvis, which are known from shallow water $(20-30 \mathrm{~cm}$ ) to a maximum of $580 \mathrm{~m}$ (KAAS \& VAN BELLE 1985; KAAS 1991), preferentially living on coralline algae. The habitat of C. XXXXXXXX is inferred from our limited data to be very restricted; to date, the species has been collected only in the "rough bottoms" of the Strait. The other records, occasionally collected from fishing boats, cannot be verified but plausibly came from the same area and environment. In the "rough bottoms", dense colonies of the hydrocoral Errina aspera, cover all the hard substrates from almost $90 \mathrm{~m}$ to $200 \mathrm{~m}$ depth, forming an exclusive facies in association with the giant barnacle Pachylasma giganteum (Philippi, 1836) (Di GERONIMO \& FreDJ 1987). Such facies are characterized by highly diversified communities that include a mixture of Atlantic subtropical (GIACOBBE \& SPANÒ 2001) and temperate (GIACOBBE \& RINELLI 1991) taxa; nevertheless, the E. aspera colonies are relatively sparsely covered in epibiota, except for the snail predators specifically associated with Pedicularia sicula, preying upon the hydrocoral polyps, and occasional epibionts such as the barnacle Megatrema anglicum (Sowerby, 1823) (DiNATALE \& MANGAnO 1985). The specimens of $C$. $X X X X X X X X$, although exclusively recorded in E. aspera samples, were always found detached. Nevertheless, their small size together with the peculiar shell roughness and pale rosaceous color, similar with the E. aspera skeleton, suggest a possible association with the hydrocoral bioconstruction.

\section{REFERENCES}

BAXTER, J.M. \& JONES, A.M. (1984) The valve morphology of Callochiton achatinus (Mollusca: Polyplacophora: Ischnochitonidae). Journal of Zoology 202: 549-560.

Bergenhayn, J.R.M. (1931) Beiträge zur Malakozoologie der Kanarischen Inseln. Arkiv for Zoologi 13: 1-35.

Bianchi, C.N., Morri, C., Chiantore, M., Montefalcone, M., Parravicini, V. \& Rovere, A. 
(2012) Mediterranean Sea Biodiversity between the Legacy From the Past and a Future of Change. Pp. 1-55 in: STAmbler, N. (Ed.) Life in the Mediterranean Sea: A Look at Habitat Changes. New York: Nova Science Publishers.

Bogi, C. \& BARTOLINI, S. (2008) Xylodiscula wareni n. sp., una nuova specie per le coste orientali della Sicilia. Iberus 26: 43-46

Bogi, C., Boyer, F., RendA, W. \& GiacobBe, S. (2016) Granulina zanclea spec. nov. (Gastropoda, Marginellidae) from the Southern Tyrrhenian Sea. Iberus 34: 97-102.

Bogi, C. \& CAMPANI, E. (2006) Jujubinus curinii n.sp.: una nuova specie di Trochidae per le coste della Sicilia. Bollettino Malacologico 41: 99-101.

Bogi, C. \& CAmpani, E. (2007) Tricolia landinii, una nuova specie per le coste orientali della Sicilia. Iberus 25: 27-31.

Buzzurro, G. \& Russo, P. (2007) Fusinus del Mediterraneo / Mediterranean Fusinus. Milano: pubblicato dagli Autori.

Capellini, J. (1859) Catalogue des oscabrions de la Méditerranée suivi de la description de quelques espèces nouvelles. Journal de Conchyliologie 7: 321-328, pl. 12.

Carmona Zalvide, P., Garcia, F.J. \& Urgorri, V. (2002) Consideraciones taxonómicos y zoogeográficas del género Callochiton Gray, 1847 en la península ibérica. Archiv für Molluskenkunde 131: 185-199.

CostA, O.G. (“1829”) [1830] Catalogo sistematico e ragionato de’ testacei delle Due Sicilie. Napoli: Tip. Minerva.

Crocetta, F., Renda, W. \& Vazzana, A. (2009) Alien Mollusca along the Calabrian shores of the Messina Strait area and a review of their distribution in the Italian seas. Bollettino Malacologico 45: 15-30.

Dell'Angelo, B., Giuntelli, P., Sosso, M. \& Zunino, M. (2016) Polyplacophora from the Miocene of North Italy. Part 2: Callochitonidae, Chitonidae, Lepidochitonidae, Acanthochitonidae and Cryptoplacidae. Rivista Italiana di Paleontologia e Stratigrafia 122: $71-102$.

Dell'Angelo B., Prelle G., Sosso M. \& Bonfitto A. (2012) A new species of Callochiton from southern Madagascar. Molluscan Research 32: 154-158.

Dell'Angelo, B. \& PAlazzI, S. (1994) Callochiton calcatus n. sp. con note su Callochiton septemvalvis (Montagu, 1803). La Conchiglia 26 (273): 15-23.

Dell'Angelo, B. \& Smriglio, C. (1999) Chitoni Viventi del Mediterraneo. Roma: Edizioni Evolver (English Ed., 2001: Living chitons of the Mediterranean).

Di Geronimo, I. \& Fredj, G. (1987) Les fonds à Errina aspera et Pachylasma giganteum. 
Documents et Travaux IGAL 11: 243-247.

Di Natale, A. \& Mangano, A. (1985) Pedicularia sicula Swainson, 1840, in the Strait of Messina: a preliminary report. Rapports Commission International Mer Méditerranée 29: 343-344.

FASUlo, G. (2013) Data di pubblicazione del 'Catalogo sistematico e ragionato de' testacei delle

Due Sicilie" di O.G. Costa. Bollettino Malacologico 49: 101-103.

GiacobBe, S. (2001) Distribuzione areale e batimetrica della facies a Errina aspera L. (Hydrozoa, Stylasteridae) nello Stretto di Messina. Biologia Marina Mediterranea 8: 246-251.

GiacobBe, S. \& Rinelli, P. (1991) Ecological notes of Ophiactis balli (Thomson) from populations of Errina aspera in the Strait of Messina. Pp. 202 in: CANICATTì, C. \& SCALERA-Liaci, L.

(Eds) Echinoderm research. Rotterdam: A.A. Balkema.

Giacobbe, S. \& Spanò, N. (2001) Pilumnus inermis (Decapoda, Brachyura) in the Strait of

Messina and the southern Tyrrhenian Sea (Mediterranean Sea): Distribution and some aspects of its ecology. Crustaceana 74: 659-672.

Giacobbe, S., IARIA, G. \& Spanò, N. (2007) Hard bottom assemblages in the Strait of Messina: distribution of Errina aspera L. (Hydrozoa: Stylasteridae). Rapports Commission International Mer Méditerranée 38: 485.

Giovine, F. \& Dell'Angelo, B. (1993) Elenco dei molluschi rinvenuti nello Stretto di Messina. Polyplacophora. Lavori S.I.M. 24: 157-170.

GRAY, J.E. (1847) A list of the genera of Recent Mollusca, their synonyms and types. Proceedings of the Zoological Society of London 15: 129-206.

Hebert, P. D. N, Cywinska, A., BALl, S. L. \& DeWAard, J. R. (2003) Biological identifications through DNA barcodes. Proceedings of the Royal Society B 270: 313-321.

KAAS, P. (1978) Notes on Loricata. 10. On the European Callochiton species. Basteria 42: 73-75.

KAAS, P. (1991) Chitons (Mollusca: Polyplacophora) procured by the CANCAP I-VII expeditions, 1976-86. Zoologische Mededelingen 65: 89-98.

KaAs, P. \& VAn Belle, R.A. (1985) Monograph of Living Chitons (Mollusca: Polyplacophora). Volume 2. Suborder Ischnochitonina, Ischnochitonidae: Schizoplacinae, Callochitoninae \& Lepidochitoninae. Leiden: E.J. Brill, W. Backhuys.

Leloup, E. (1934) Contribution a la connaissance de la faune des Chitons de Villafranche-sur-mer et des environs (France, Mediterranee). Bulletin de Musée royal d'Histoire naturelle de Belgique 10 (47): 1-20.

Monterosato, M.T.A. (1879) Enumerazione e sinonimia delle conchiglie mediterranee.

Monografia dei Chitonidi del Mediterraneo. Giornale di Scienze Naturali ed Economiche 14: $1-31$. 
Okusu, A., Schwabe, E., Eernisse, D. J. \& Giribet, G. (2003) Towards a phylogeny of chitons

(Mollusca, Polyplacophora) based on combined analysis of five molecular loci. Organisms, Diversity \& Evolution 3: 281-302.

RendA, W. \& MicAli, P. (2016) Vetulonia giacobbei n. sp. from south Tyrrhenian Sea (Gastropoda, Seguenzioidea). Bollettino Malacologico 52: 56-59.

SCHWABE, E. (2010) Illustrated summary of chiton terminology. Spixiana 33: 171-194.

Sigwart, J.D., Stoeger, I., Knebelsberger, T. \& Schwabe, E. (2013) Chiton phylogeny

(Mollusca : Polyplacophora) and the placement of the enigmatic species Choriplax grayi $(\mathrm{H}$.

Adams \& Angas). Invertebrate Systematics 27: 603-621.

Smriglio, C., Mariottini, P. \& GiacobBe, S. (2016) Jujubinus errinae n. sp. (Gastropoda

Trochidae) from the Strait of Messina, Mediterranean Sea. Biodiversity Journal 7: 59-66.

THIELE, J. (1902) Die systematische Stellung der Solenogastren und die Phylogenie der Mollusken. Zeitschrift für wissenschaftliche Zoologie 72: 249-466, pls 18-27.

Tisselli, M., AgAmennone, F. \& GiUnCHI, L. (2009) Una nuova specie di Gibberula (Gastropoda: Cystiscidae) per il Mediterraneo. Bollettino Malacologico 45: 49-53.

Wilson, N. G., Rouse, G. W. \& GiRIBET, G. (2010) Assessing the molluscan hypothesis Serialia (Monoplacophora+ Polyplacophora) using novel molecular data. Molecular Phylogenetics and Evolution 54: 187-193. 